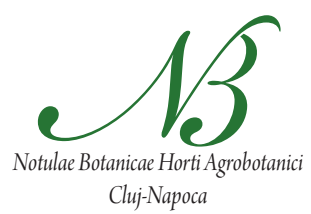

\title{
Breeding Objectives and Selection Criteria for Milk Thistle [Silybum marianum (L.) Gaertn.] Improvement
}

\author{
Ali ALEMARDAN ${ }^{1}$, Anestis KARKANIS²* Reza SALEHI ${ }^{1}$ \\ ${ }^{1}$ Department of Horticultural Sciences, Campus of Agriculture and Natural Resources, University of Tehran, 31587-77871, Karaj, Iran \\ ${ }^{2}$ Department of Agriculture Crop Production and Rural Environment, University of Thessaly, Fytokou \\ Str, 38446, Nea Ionia, Magnesia, Greece; anekark80@yahoo.gr ("corresponding author)
}

\begin{abstract}
Milk thistle [Silybum marianum (L.) Gaertn.] is an important medicinal-industrial plant. The medicinal compounds of milk thistle are derived from its seeds. The plant is commercially cultivated for the production of silymarin. Cultivation offers the opportunity to optimise achene yield and silymarin content. Furthermore, efforts should be made to develop new cultivars. The main objective of milk thistle breeding is to develop high yielding cultivars with elevated silymarin content. There are few developed cultivars of milk thistle (e.g. Argintiu, Budakalaszi, Szibilla, Khoreslo, Babak Castle, Mirel, Silma and Silyb). Different genotypes of milk thistle have variable amount of silymarin e.g. a 'Royston' genotype is rich in silymarin (6-10\%). Further progress can be made by using the genetic diversity available in abundance in different genotypes. The main concern of the breeder should be to increase the yield and silymarin contents of the seeds. Asynchronous flowering and seed shedding are also major problems in milk thistle cultivation. At the time of harvest, the plants have flower heads at all stages of development resulting non-uniform maturation of seeds. Therefore, a breeding effort in milk thistle should be planned to obtain plants with simultaneous flowering and reduced crop losses. The developed cultivar Argintiu is characterised by simultaneous seed maturation in flower heads. The wild populations, as valuable gene pools, could be exploited for the improvement of milk thistle crop.
\end{abstract}

Keywords: achene shedding, breeding approaches, selection criteria, silymarin

\section{Introduction}

Many of the medicinal plants belong to the family Asteraceae. Plants of the genera Calendula, Silybum, Vernonia are widely used in ethnomedicine (Ercetin et al., 2012; Toyang and Verpoorte, 2013; Karkanis et al., 2011). Silybum marianum (milk thistle) seeds have been used as medicine for over 2000 years. Theophrastus $\left(4^{\text {th }}\right.$ century BCE) described it under the name "Pternix" and Dioscorides used the name "Sillybom" in Materia Medica [ $1^{\text {th }}$ century CE] and prescribed the use of its tea for snake bites (Corchete, 2008). Silymarin is the main active ingredient of the milk thistle seeds. Significance of silymarin and its components in the medicine is clearly indicated by an exponential growth of publications on this topic [over 800 papers in the last 5 years (Gazák et al., 2007). Silymarin is an extract of milk thistle that has a multitude of biological activities (Polyak et al., 2010). It is considered safe and well-tolerated, with gastrointestinal upset, a mild laxative effect, and rare allergic reaction being the only adverse events reported when taken within the recommended dose range (Post-White et al., 2007).

Milk thistle seeds extract and its constituents are antioxidant and hepatoprotective (Bhattacharya, 2011). Silymarin has been used to treat alcoholic liver disease, acute and chronic viral hepatitis and toxin-induced liver diseases (Abenavoli et al., 2010). Silymarin inhibits hepatitis $\mathrm{C}$ virus (HCV) infection and also displays antioxidant, anti-inflammatory, and immunomodulatory actions that contribute to its hepatoprotective effects (Polyak et al., 2010).

Moreover, milk thistle is increasingly being investigated for its use in adult and pediatric populations for oncology indications. Possible indications during cancer treatment include cleansing and detoxification after chemotherapy, preventing hepatotoxicity during chemotherapy, treating hepatotoxicity after chemotherapy, and potentiating chemotherapy and radiation therapy as an adjunctive treatment (Greenlee et al., 2007). Silymarin is a promising agent for cancer prevention, adjuvant cancer treatment, and reduction of iatrogenic toxicity (Sagar, 2007). Silibinin has been shown to possess anti-neoplastic properties (Deep and Agarwal, 2010; Kauntz et al., 2012).

Moreover, milk thistle seeds contain a relatively high level of oil (18-31\%) [Ghavami and Ramin, 2008; Rưžičková et al., 2011]. This oil is rich in unsaturated fatty acids principally linoleic acid (42-54\%) and oleic acid (21$36 \%)$. Thus, it is suitable for human use (El-Mallah et al., 2003; Gresta et al., 2006; Fathi-Achachlouei and Azadmard-Damirchi, 2009; Malekzadeh et al., 2011). 
Biotechnological methods can be used to obtain silymarin (Tab. 1). Silymarin synthesis in cell and tissue cultures of $S$. marianum has been reported (Hasanloo et al., 2008; Khalili et al., 2009; Elwekeel et al., 2012). The treatment of plant cells and tissues with elicitors (i.e. methyl jasmonate) has been a useful strategy to enhance silymarin synthesis in cell and tissue cultures (Sánchez-Sampedro et al., 2005a \& b; Elwekeel et al., 2012). Elicitors are molecules that improve the synthesis of plant secondary metabolites. Nonetheless, silymarin levels in in-vitro cultures are much lower than those detected in the seeds (Madrid and Corchete, 2010). Presently, silymarin is extracted from the dried milk thistle achenes. Therefore, efforts should be made to develop high yielding cultivars with elevated silymarin level. In this review, an effort has been made to present the main trends in milk thistle breeding and improvement.

Tab. 1. Examples of biotechnological methods used to produce silymarin.

\begin{tabular}{|c|c|c|c|c|}
\hline $\begin{array}{l}\text { Culture } \\
\text { method }\end{array}$ & Explant & Elicitor & $\begin{array}{c}\text { Silymarin } \\
\text { content } \\
(\%)\end{array}$ & Reference \\
\hline $\begin{array}{l}\text { Callus } \\
\text { culture }\end{array}$ & $\begin{array}{l}\text { Germinating } \\
\text { seeds }\end{array}$ & $\begin{array}{c}\text { Amides of } \\
\text { carboxylic } \\
\text { acids }\end{array}$ & 0.107 & $\begin{array}{l}\text { Tůmová et } \\
\text { al., (2010) }\end{array}$ \\
\hline $\begin{array}{c}\text { Cell } \\
\text { suspension }\end{array}$ & $\begin{array}{l}\text { Hypocotyls } \\
\text { segments from } \\
10 \text { day-old } \\
\text { seedlings }\end{array}$ & $\begin{array}{c}\text { Yeast extract } \\
\text { +methyl } \\
\text { jasmonate }\end{array}$ & 1.36 & $\begin{array}{c}\text { Sánchez- } \\
\text { Sampedro et } \\
\text { al., (2005a) }\end{array}$ \\
\hline $\begin{array}{c}\text { Cell } \\
\text { suspension }\end{array}$ & $\begin{array}{l}\text { Hypocotyls } \\
\text { segments from } \\
10 \text { day-old } \\
\text { seedlings }\end{array}$ & $\begin{array}{c}\text { Calcium } \\
\text { deprivation }\end{array}$ & 0.68 & $\begin{array}{c}\text { Sánchez- } \\
\text { Sampedro et } \\
\text { al., (2005b) }\end{array}$ \\
\hline $\begin{array}{c}\text { Cell } \\
\text { suspension }\end{array}$ & $\begin{array}{c}\text { Cotyledon, } \\
\text { shoot and } \\
\text { root segments }\end{array}$ & $\begin{array}{c}\text { Picloram, } \\
\text { jasmonic acid }\end{array}$ & 0.041 & $\begin{array}{c}\text { Hasanloo et } \\
\text { al., (2008) }\end{array}$ \\
\hline Hairy roots ${ }^{*}$ & $\begin{array}{l}\text { Hypocotyls, } \\
\text { leaves and } \\
\text { cotyledons } \\
\text { segments }\end{array}$ & Salicylic acid & 0.189 & $\begin{array}{l}\text { Khalili } e t \\
\text { al., (2009) }\end{array}$ \\
\hline Hairy roots & $\begin{array}{l}\text { 4-week-old } \\
\text { seedlings }\end{array}$ & -.---.-- & 0.002 & $\begin{array}{c}\text { Alikaridis et } \\
\text { al., }(2000)\end{array}$ \\
\hline $\begin{array}{c}\text { Root } \\
\text { cultures }\end{array}$ & $\begin{array}{l}\text { 10-day-old } \\
\text { plants }\end{array}$ & $\begin{array}{c}\text { Methyl } \\
\text { jasmonate }\end{array}$ & $0.007-0.014$ & $\begin{array}{l}\text { Elwekeel } e t \\
\text { al., (2012) }\end{array}$ \\
\hline
\end{tabular}

${ }^{*}$ Hairy root cultures are the roots obtained by genetic transformation of plant tissues with the pathogenic soil bacterium Agrobacterium rhizogenes (Elwekeel et al., 2012)

\section{Botanical and morphological description}

Milk thistle (Silybum marianum. L. Gaertn. syn.: Carduus marianus L.) is a member of the Asteraceae family. Its generic name is derived from a Greek word "Silybon" or "Silybos" which means tassel or tuft. It is an annual or biennial species occurring throughout the world (Sidhu and Saini, 2011). The genus Silybum has two species namely
S. eburneum Coss. \& Dureu and S. marianum. The crossing experiments between $S$. marianum and $S$. eburneum has produced F1-plants having variegated leaf which is a characteristic of $S$. marianum. The F2 progenies had completely green and variegated leaves in a ratio of about $3: 1$ indicating that the leaf colour is monofactorially inherited and also the two species are only variants (Adzet et al., 1993; Hetz et al., 1995).

Milk thistle (Fig. 1.) can attain a height of two meters and has dark shiny green and white-veined leaves with spiny edges (Carrier et al., 2003; Gresta et al., 2006; Morazzoni and Bombardelli, 1995). The inflorescences are solitary large heads located at the apex of the stem, or at the primary and secondary branches. The florets are hermaphrodite, tubular in shape, with a red-purple or white corolla (Gresta et al., 2006; Corchete, 2008; Vaknin et al., 2008). Milk thistle is predominantly a self-pollinator (Hetz et al., 1995). The shape of the pollen grains in milk thistle is prolate in equatorial view and semi angular in polar view (Ahmad et al., 2008). The seeds are hard-skinned achenes (Fig. 2), 6-8 mm long, shiny, generally brownish in colour and with a white pappus at the apex (Corchete, 2008).

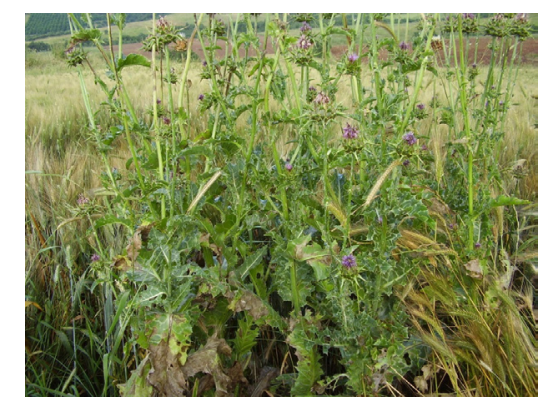

Fig. 1. Milk thistle (Silybum marianum)

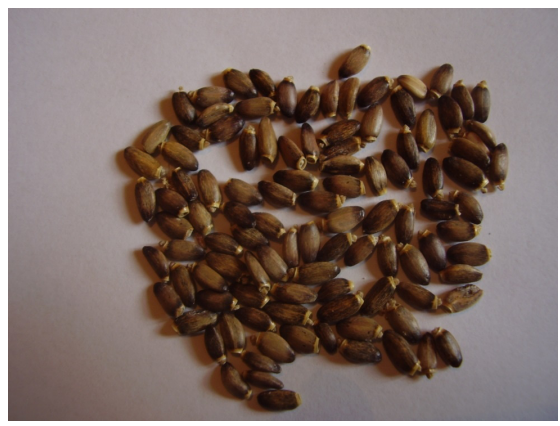

Fig. 2. Seeds of milk thistle

\section{Cytology of Silybum marianum}

Silybum marianum is a diploid species with $2 \mathrm{n}=2 \mathrm{x}=34$ chromosomes. The karyotype consists of six pairs of metacentric, ten pairs of submetacentric and one pairs of acrocentric chromosomes (Asghari-Zakaria et al., 2008). 
342

\section{Distribution and habitat}

Milk thistle is an herb native of the Mediterranean region and which has also spread in Central Europe, Central and East Asia, North and South America and Southern Australia (Montemurro et al., 2007). Moreover, milk thisthe is a common weed in cereal crops (Khan et al., 2009, Veres and Tyr, 2012). Also, this weed is commonly found growing in waste places (Gabay, 1994) and along the roadsides (Karkanis et al., 2011). Additionally, it is grown as an ornamental plant for its unusual and attractive foliages (Bhattacharya, 2011). Furthermore, the high growth rates of milk thistle make it interesting for biomass production for energy (Sulas et al., 2008). Ledda et al. (2013) noted that annual biomass production across years averaged about 10.000 , 4.000, and $16.000 \mathrm{Kg} \mathrm{ha}^{-1}$ in cardoon (Cynara cardunculus L. var. altilis, Asteraceae), globe artichoke (Cynara cardunculus L. var. scolymus, Asteraceae) and milk thistle, respectively.

\section{Milk thistle active constituents-chemotypes}

The crude commercial product of milk thistle is termed silymarin (Fig. 3), a complex of at least 7 flavonolignans (silybin A, silybin B, isosilybin A, isosilybin B, silychristin, isosilychristin, silydianin) and 1 flavonoid (taxifolin). From silymarin is derived silibinin, a semipurified fraction once thought to be a single compound but now recognised as a 1:1 mixture of 2 diastereoisomers, silybin A and silybin B (Kroll et al., 2007).

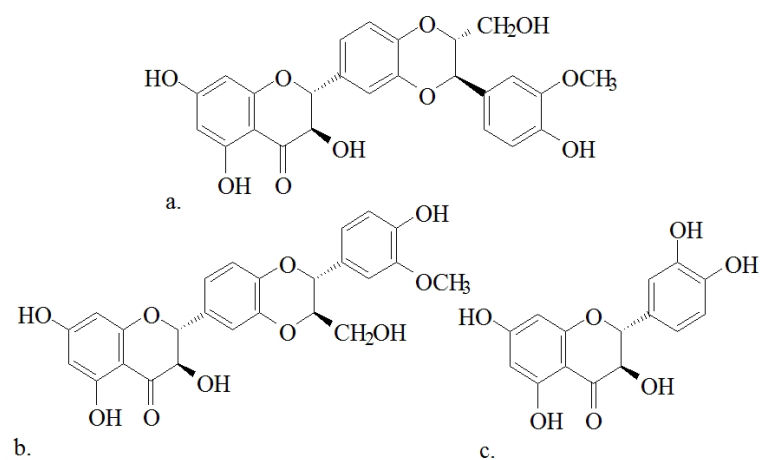

Fig. 3. The chemical structure of milk thistle active constituents: a) silybin, b) isosilybin (flavonolignans) and c) taxifolin (flavonoid)

The content and composition of silymarin depends on milk thistle genotypes. There are two botanical varieties for $S$. marianum based on flower colour. The purple variety contains 3-OH-flavonolignans, mainly silybin, isosilybin, silydianin and silychristin (Adzet et al., 1993), while white flower variety in addition contains 3-deoxy-flavonolignans: silandrin, isosylandrin, silymonin, silyhermin and neosilyhermin (Szilági et al., 1981; Samu et al., 2004; Nyiredy et al., 2008). Two chemotypes are identified for purple variety (Tab. 2), one with a high level of silybin (high silybin:silydianin ratio) and another with a high level of silydianin (low silybin:silydianin ratio). Furthermore, a milk thistle genotype of Indian origin contained a high level of silychristin and dehydrosilybin, a low level of silybin and no silydianin (Adzet et al., 1993). The absence of silydianin is also reported in a New Zealand line (Martin et al., 2006).

Tab. 2. Milk thistle types and flavonolignan constituents

\begin{tabular}{|c|c|c|}
\hline Variety & Components & References \\
\hline $\begin{array}{l}\text { S. marianum (milk } \\
\text { thistle-purple flower): }\end{array}$ & 3-OH-flavonolignans & Adzet et al. (1993); \\
\hline 1. Silybin type & $\begin{array}{l}\text { High silybin:silydianin } \\
\text { ratio }\end{array}$ & Martin et al. (2006) \\
\hline 2. Silydianin type & Low silybin:silydianin ratio & \\
\hline $\begin{array}{l}\text { 3. Silychristin/ } \\
\text { dehydrosilybin type }\end{array}$ & $\begin{array}{l}\text { High silychristin and } \\
\text { dehydrosilybin, low } \\
\text { silybin, no silydianin }\end{array}$ & \\
\hline $\begin{array}{l}\text { S. marianum (milk } \\
\text { thistle-white flower) }\end{array}$ & $\begin{array}{l}\text { 3-deoxy and 3-OH- } \\
\text { flavonolignans }\end{array}$ & $\begin{array}{l}\text { Szilági et al. (1981); } \\
\text { Samu et al. (2004); } \\
\text { Nyiredy et al. (2008) }\end{array}$ \\
\hline $\begin{array}{l}\text { S. eburneum (green } \\
\text { milk thistle) }\end{array}$ & High isosilychristin & Martin et al. (2006) \\
\hline
\end{tabular}

Milk thistle has been commercially cultivated for the production of silymarin. Depending on climatic conditions and cultivated genotype, achene yield varies from 400 to $2000 \mathrm{~kg} / \mathrm{ha}$ (Karkanis et al., 2011). The silymarin content in seeds also depends on the cultivated genotypes and environmental conditions. Hevia et al., (2007) observed that silymarin content in Chilean genotype was higher than German one. In addition, Martin et al. (2006) reported that the New Zealand line had a significantly higher percentage of silychristin A and silybins $\mathrm{A}$ and $\mathrm{B}$ than the German cultivar.

\section{Breeding of milk thistle crop}

Genetic improvement in Silybum marianum can only be achieved through a clear understanding of the plant's behaviour and the amount of variability presented in wild populations, including genotypes which may represent the maximum expression of adaptation capability to environmental conditions (Gresta et al., 2006). The wild populations from different geographical regions constitute a gene pool that can be utilised for the improvement of milk thistle crop (Shokrpour et al., 2008b).

Molecular markers [e.g. Amplified fragment length polymorphism (AFLP) markers] could be useful for selecting appropriate populations to improve $S$. marianum through conventional and molecular breeding (Mohammadi et al., 2011). Mutation breeding is also a useful method for plant improvement. Katar et al. (2013) observed that the most efficient doses of gamma rays for mutation breeding program of milk thistle could be 200-400 Gy. 
Tab. 3. Milk thistle cultivars or cultivated genotypes

\begin{tabular}{|c|c|c|}
\hline Cultivars & Country & References \\
\hline $\begin{array}{l}\text { Mirel } \\
\text { Silyb }\end{array}$ & Czech Republic & Růžičková et al., (2011) \\
\hline $\begin{array}{l}\text { Unnamed (from } \\
\text { CN Seeds, Ltd.) }\end{array}$ & England & $\begin{array}{c}\text { Shokrpour et } \\
\text { al., (2008a) }\end{array}$ \\
\hline Royston & Germany & $\begin{array}{l}\text { Ghavami and } \\
\text { Ramin, (2008) }\end{array}$ \\
\hline $\begin{array}{l}\text { Budakalaszi } \\
\text { Szibilla }\end{array}$ & Hungary & $\begin{array}{c}\text { Shokrpour et } \\
\text { al., (2008a) } \\
\text { Béla, (2007) }\end{array}$ \\
\hline $\begin{array}{c}\text { Khoreslo } \\
\text { Babak Castle }\end{array}$ & Iran & $\begin{array}{c}\text { Fathi-Achachlouei } \\
\text { and Azadmard- } \\
\text { Damirchi, (2009) }\end{array}$ \\
\hline Silma & Poland & $\begin{array}{c}\text { Kaźmierczak and } \\
\text { Seidler-Łożykowska, } \\
(1997)\end{array}$ \\
\hline Argintiu & Republic of Moldova & Gonceariuc, (2007) \\
\hline
\end{tabular}

In breeding a new cultivar of medicinal plants, single plants with high performance (yield and quality) are selected from as many sources as possible. These single plants are tested in the same soil and climate conditions that later on will be the place of commercial production. The next step is to produce "families", by self-pollination, from each one of the selected plants, and again to choose only the best ones during 4 to 7 generations until a uniform line is obtained. Thus, a new cultivar is "born" (Dudai, 2012).

The cultivar Argintiu has been developed in the Republic of Moldova. Gonceariuc (2007) reported that this cultivar was developed by inbreeding lines of different origins and polycross hybridisation among the obtained inbred lines, followed by selection of genotypes in early generations (F2-F4). This cultivar has advantages in terms of earliness, high yield, medium height $(136 \mathrm{~cm})$, short flowering period, uniform maturity and drought-disease resistance.

The main approaches in milk thistle improvement are enhancement of seed and silymarin yield, breeding for biotic and abiotic stress resistant/tolerant cultivars, development cultivars with simultaneous flowering, reduced thorns and achene shedding.

\section{Enhanced achene yield and silymarin content}

A number of different genotypes are available. Seed number and weight are the most important milk thistle yield components (Shokrpour et al., 2011). In addition, variation in the achene weight between primary and secondary flower heads suggests that it might be possible to increase achene yield by re-designing an "ideotype" with less secondary branches and applying the appropriate crop management (Gresta et al., 2006).

Shokrpour et al. (2011) observed considerable variation among the studied genotypes for the milk thistle yield components (achene number per head, achene weight in head and head diameter). Furthermore, Ram et al. (2005) reported that the seed yield/plant and number of heads/ plant had highest estimates of genotypic variation, heritability and genetic advance which suggest that direct selection for these traits is suitable for the improvement of milk thistle. Number of heads/plant had a significant positive correlation with the number of branches/plant and leaf length ( $\mathrm{r}=0.339$ and 0.754 , respectively), whereas achene yield/plant had a positive significant correlation with leaf length, stem diameter and head diameter $(\mathrm{r}=0.683,0.314$, and 0.348, respectively) (Ram et al., 2005). Andrzejewska and Sadowska (2008), Ottai and Abdel-Moniem (2006) and Gresta et al. (2006) reported that seeds yield had a high positive significant correlation with plant height. Additionally, Gresta et al. (2006) reported that a breeding effort in milk thistle should be planned to obtain taller plants and first branch insertions, since they reduce the number of secondary flower heads.

The silymarin content (Tab. 4) most often ranges from $1.0 \%$ to $3.0 \%$ of achene dry matter but can exceed 8\% (Karkanis et al., 2011). Ghavami and Ramin (2008) observed that two genotypes of milk thistle (Royston and Iranian wild type) produced seeds rich in silymarin (6-10\%). Efforts should be made to develop cultivars with high silymarin content. Ibrahim et al. (2007) observed that the silymarin production has the same pattern of achene yield trait, so selection should be based on this trait to produce new improved yielding silymarin genotypes. Moreover, Andrzejewska and Sadowska (2008) and Ram et al. (2005) observed that the achene yield/plant had a positive significant correlation with silymarin content.

Tab. 4. Silymarin content in selected locations where milk thistle is grown

\begin{tabular}{|c|c|c|}
\hline Place & $\begin{array}{c}\text { Silymarin } \\
\text { content (\%) }\end{array}$ & References \\
\hline Bulgaria (Sofia) & $0.6-5.62$ & Geneva et al., (2008) \\
\hline Canada (Saskatchewan) & $2.36-2.92$ & Carrier et al., (2003) \\
\hline Chile (Concepción) & $3.7-5.7$ & Hevia et al., (2007) \\
\hline India (Jammu region) & $2.00-3.56$ & Ram et al., (2005) \\
\hline Iran (Ahwaz) & $6-10.2$ & $\begin{array}{l}\text { Ghavami and } \\
\text { Ramin, (2008) }\end{array}$ \\
\hline $\begin{array}{c}\text { Iran } \\
(\text { Borazjan, Roodbarak) }\end{array}$ & $2.46,2.71$ & Hasanloo et al., (2005) \\
\hline Iran (Tabriz) & $1.43-1.52$ & $\begin{array}{l}\text { Shokrpour et } \\
\text { al., (2008b) }\end{array}$ \\
\hline $\operatorname{Iran}($ Tehran $)$ & $5.10-8.60$ & Hadi et al., (2008) \\
\hline New Zealand (Lincoln) & $1.03-4.27$ & Martin et al., (2006) \\
\hline Poland (Bydgoszcz) & $1.91-2.89$ & $\begin{array}{l}\text { Kozera and Nowak, } \\
\text { (2004)- Andrzejewska } \\
\text { and Sadowska, (2008) }\end{array}$ \\
\hline Poland (Mochelek) & $1.65-2.48$ & $\begin{array}{l}\text { Andrzejewska } \\
\text { et al., (2011) }\end{array}$ \\
\hline Slovakia (Nitra) & $1.51-2.00$ & Haban et al., (2009) \\
\hline
\end{tabular}

Silybin is the main component (ca. 30\%) of the silymarin complex extracted from the achenes of Silybum marianum (Jančová et al., 2011; Zarelli et al., 2013). Ecotypes 
344

with higher 1000 achene weight; earlier flowering date; lower height and capitula diameter had higher silychristin and silybin and lower silydianin content (Shokrpour $e$ t al., 2008a).

\section{Synchronous maturity}

Asynchronous flowering is a major problem in milk thistle crop. The flowering of milk thistle heads is dispersed in time and space, so the ripeness is not simultaneous in the whole plant (Curioni et al., 2002). At the time of harvest, the plants have flower heads at all stages of development (Carrier et al., 2003). In the Republic of Moldova, the developed cultivar Argintiu is characterised by simultaneous seed maturation in flower heads (Gonceariuc, 2007). Furthermore, a breeding effort in milk thistle should be planned to obtain plants with lower secondary flower heads (Gresta et al., 2006).

\section{Reduced achene shedding}

Significant crop losses occur in milk thistle due to natural shedding and crop disturbance by harvesting machinery. More plant height and asynchronous maturity makes harvesting generally more difficult. Milk thistle producers have reported more than $50 \%$ loss in crop yield. Therefore, reducing achene shedding is one of the most challenging objectives of milk thistle breeding. However, asynchronous flowering is associated with achene shedding. Additionally, tall genotypes are generally more susceptible to lodging than the short-medium genotypes. Therefore, a breeding effort in milk thistle should be planned to obtain plants with lower height. Ottai and Abdel-Moniem (2006) observed wide diversity for plant height. The height of white variety was $150-185 \mathrm{~cm}$ and purple variety measured up to $117-151 \mathrm{~cm}$. Moreover, the Argintiu cultivar is medium in height $(136 \mathrm{~cm})$ (Gonceariuc, 2007). For rapid evaluation of genotypes, molecular markers could be effective tools in breeding programs. Shokrpour et al. (2008a) reported that AFLP markers estimated more than $40 \%$ of milk thistle height variation.

\section{Reduced spines}

Milk thistle is very spiny which is a problem. Khan $e t$ al. (1988) tried to produce spineless mutants using radiation. However, their attempts were unsuccessful.

\section{Resistance/tolerance against abiotic stresses}

Milk thistle is considered drought resistant (Carrubba and La Torre, 2003; Karkanis et al., 2011). Sidhu and Saini (2011) observed that the stomata are usually absent in the epidermal layers of leaves which is a distinct feature. In spite of this, milk thistle genotypes respond differently in drought stress. The drought tolerant genotypes could be exploited in breeding programs for developing cultivars with enhanced drought tolerance. Deliri et al. (2010) observed that the root volume and root dry weight could be used as reliable criteria in selection for drought stress tolerant genotypes in milk thistle. In Iran, 'Ghaemieh' ecotype is recognised as drought tolerant (Deliri et al., 2010). Moreover, salinity can affect growth and development of milk thistle plants. Ghavami and Ramin (2008) observed that two genotypes of milk thistle (Royston and Iranian wild type) survived at a high salinity of $15 \mathrm{dS} \mathrm{m}^{-1}$ and produced seeds rich in silymarin.

\section{Resistance/tolerance against biotic stresses}

Milk thistle is susceptible to a range of diseases and pests. Puccinia punctiformis, Microbotryum silybum and Septoria silybi have been reported as pathogens of milk thistle (Moscow and Lindow, 1989; Berner et al., 2002; Souissi et al., 2005). Furthermore, milk thistle is susceptible to the insects Terellia fuscicornis, Larinus latus, Cleonus piger, Nezara viridula, Dysaphis lappae cynarae and Aphis fabae cirsiiacanthoidis (Clarke and Walter, 1993; Abdel-Moniem, 2002, Andrzejewska et al., 2006; Kavallieratos et al., 2007; Rezwani, 2008; Sayar et al., 2009). Andrzejewska et al. (2006) observed that the infestation and density of Cleonuspiger larvae in roots of plants grown in monoculture increased with subsequent developmental phases and subsequent years of the experiment. Feeding resulted in the decrease in crop yield by $40 \%$ compared to the crop rotation treatment. Ottai and Abdel-Moniem (2006) reported that life cycle of $L$. latus was longer $(60$ days), when larvae reared on white variety comparing with the life cycle (58 days) of the insect, when larvae reared on purple variety. Thus, efforts should be made to develop cultivars resistant to diseases and insects.

\section{Increased oil content and quality}

Milk thistle is considered as an alternative oil crop and a few investigations are conducted about diversity of seed oil. In Czech Republic, the Mirel cultivar is a superior genotype in term of quality of seed oil with about $66 \%$ linoleic acid (Fathi-Achachlouei and Azadmard-Damirchi, 2009; Růžičková et al., 2011).

\section{Conclusions}

The main objective of milk thistle breeding is to develop high yielding cultivars. The genetic diversity available in different milk thistle genotypes is the best source that can be used in the development of high yielding genotypes with elevated silymarin content. There is also an interesting positive relationship between achene yield and silymarin content which would be a very helpful criterion for developing new superior cultivars. Asynchronous flowering and achene shedding are also major problems in milk thistle cultivation. Therefore, a breeding effort in milk thistle should be planned to obtain plants with synchronous flowering to reduce crop losses. For rapid evaluation of wild genotypes, molecular markers are effective tools in breeding programs. 


\section{References}

Abdel-Moniem ASH (2002). The seed-head weevil, Larinus latus Herbst (Coleoptera: Curculionidae) as a new record in Egypt on the milk thistle, Silybum marianum (L.)(Asteraceae: Compositae). Arch Phytopathol Plant Prot 35:157-160.

Abenavoli L, Capasso R, Milic N, Capasso F (2010). Milk thistle in liver diseases: past, present, future. Phytother Res 24(10): 1423-1432.

Adzet T, Iglesias J, Martinez F (1993). Flavonolignans in the fruits of Silybum genus taxa: a chromatographic and mass spectrometric survey. Plantes Med Phytother 26(2):117129.

Ahmad M, Khan MA, Hasan A, Zafar M, Sultana S (2008). Chemotaxonomic standardization of herbal drugs milk thistle and globe thistle. Asian J Chem 20:4443-4459.

Alikaridis UF, Papadakis D, Pantelia K, Kephalas T (2000). Flavonolignan production from Silybum marianum transformed and untransformed root cultures. Fitoter 71:379384.

Andrzejewska J, Lamparski R, Skinder Z (2006). Assessing the extent of damage caused by Cleonus piger Scop. and other entomofauna in the cultivation of milk thistle (Silybum marianum (L.) Gaertn). J Plant Prot Res 46:49-59.

Andrzejewska J, Sadowska K (2008). Effect of cultivation conditions on the variability and interrelation of yield and raw material quality in milk thistle. Acta Sci Pol Agric 7(3): 3-11.

Andrzejewska J, Sadowska K, Mielcarek S (2011). Effect of sowing date and rate on the yield and flavonolignan content of the fruits of milk thistle (Silybum marianum L. Gaertn.) grown on light soil in a moderate climate. Ind Crops Prod 33:462-468.

Asghari-Zakaria R, Panahi AR, Sadeghizadeh M (2008). Comparative study of chromosome morphology in Silybum marianum. Cytol 73(3):327-332.

Béla D (2007). Formation of flavanolignane in the white-flowered variety (Szibilla) of Silybum marianum in relation to fruit development. Acta Pharm Hung 77(1):47-51.

Berner DK, Paxson LK, Bruckart WL, Luster DG, McMahon M, Michael JL (2002). First report of Silybum marianum as a host of Puccinia punctiformis. Plant Dis 86:1271.

Bhattacharya S (2011). Phytotherapeutic properties of milk thistle seeds: An overview. J Adv Pharm Educ Res 1:69-79.

Carrier DJ, Crowe T, Sokhansanj S, Wahab J, Barl B (2003). Milk Thistle, Silybum marianum (L.) Gaertn., flower head development and associated marker compound profile. J Herbs Spices Med Plants 10(1):65-74.

Carrubba A., La Torre R (2003). Cultivation trials of milk thistle (Silybum marianum Gaertn.) into the semiarid Mediterranean environment. Agric Medit 133:14-19.

Clarke AR, Walter GH (1993). Variegated thistle (Siybum marianum (L.)), a non-crop host plant of Nezara viridula (L.)
345

(Hemiptera: Pentatomidae) in South-eastern Queensland. Aust J Entomol 32:81-83.

Corchete P (2008). Silybum marianum (L.) Gaertn: the source of silymarin. In: Ramawat KG, Merillon JM, editors. Bioactive Molecules and Medicinal Plants. Springer, p. 123-148.

Curioni A, Carcía M, Alfonso W, Arizio O (2002). Predicción de la cosecha de cardo mariano a través de las características externas que presentan los capítulos. Acta Hortic 569:257261.

Deep G, Agarwal R (2010). Antimetastatic efficacy of silibinin: molecular mechanisms and therapeutic potential against cancer. Cancer Metastasis Rev 29(3):447-463.

Deliri R, Shokrpour M, Asghari A, Esfandiari E, Seyed Sharifi R (2010). Assessment of milk thistle ecotypes for drought resistance in a hydroponic System. J Sci Technol Greenh Cult $1(1): 9-18$.

Dudai N (2012). Domestication and breeding of wild medicinal and aromatic plants-Thirty years of experience in Israel. Acta Hortic 955:175-183.

El-Mallah MH, El-Shami SM, Hassanein MM (2003). Detailed studies on some lipids of Silybum marianum (L.) seed oil. Grasas Aceites 54(4):397-402.

Elwekeel A, Elfishway A, AbouZid S (2012). Enhanced accumulation of flavonolignans in Silybum marianum cultures roots by methyl jasmonate. Phytochem Lett 5:393-396.

Ercetin T, Senol FS, Erdogan Orhan I, Toker G (2012). Comparative assessment of antioxidant and cholinesterase inhibitory properties of the marigold extracts from Calendula arvensis L. and Calendula officinalis L. Ind Crops Prod 36 (1):203-208.

Fathi-Achachlouei B, Azadmard-Damirchi S (2009). Milk Thistle seed oil constituents from different varieties grown in Iran. J Am Oil Chem Soc 86:643-649.

Gabay R, Plitmann U, Danin A (1994) Factors affecting the dominance of Silybum marianum L. (Asteraceae) in its specific habitats. Flora 189:201-206.

Gazák R, Walterová D, Kren V (2007). Silybin and silymarin-new and emerging applications in medicine. Curr Med Chem 4 (3):315-338.

Geneva M, Stancheva I, Sichanova M, Boycinova M, Georgiev G, Dolezal M (2008). Improvement of milk thistle (Silybum marianum L.) seed yield and quality with foliar application and growth effector MD 148/II. Gen Appl Plant Physiol 34:309-318.

Ghavami N, Ramin AA (2008). Grain yield and active substances of milk thistle as affected by soil salinity. Commun Soil Sci Plant Anal 39(17-18):2608-2618.

Gonceariuc M (2007). Some breeding results of Silybum marianum Gertn. Rom Biol Sci 5(1/2):52-53.

Greenlee H, Abascal K, Yarnell E, Ladas E (2007). Clinical applications of Silybum marianum in oncology. Integr Cancer Ther 6(2):158-165.

Gresta F, Avola G, Guarnaccia P (2006). Agronomic character- 
346

ization of some spontaneous genotypes of milk thistle (Silybum marianum L. Gaertn.) in Mediterranean Environment. J Herbs Spices Med Plants 12(4):51-60.

Haban M, Otepka P, Kosiba L, Habanova M (2009). Production and quality of milk thistle (Silybum marianum (L.) Gaertn.) cultivated in cultural conditions of warm agri-climatic macroregion. Hortic Sci 36:25-30.

Hadi HS, Darzi M, Ashoorabadi SE (2008). Study of the effects of conventional and low input production systems on quantitative and qualitative yield of Silybum marianum L. cultivating the future based on science, 1 . In: $2^{\text {nd }}$ Conference of the International Society of Organic Agriculture Research ISOFAR, Modena, Italy. pp. 738-741.

Hasanloo T, Khavari-Nejab RA, Majidi E, Shams-Ardekani MR (2005). Analysis of flavonolignans in dried fruits of Silybum marianum (L.) Gaertn from Iran. Pak J Biol Sci 8 (12):1778-1782.

Hasanloo T, Khavari-Nejab RA, Majidi E, Shams-Ardekani MR (2008). Flavonolignan production in cell suspension culture of Silybum marianum. Pharm Biol 46(12):876-882.

Hetz E, Liersch R, Schieder O (1995). Genetic investigations on Silybum marianum and S. eburneum with respect to leaf colour, outcrossing ratio, and flavonolignan composition. Planta Medic 61(1):54-57.

Hevia F, Wilckens RL, Berti MT, Fischer SU (2007). Quality of milk thistle (Silybum marianum (L.) Gaertn.) harvested in different phenological stages. Inf Technol 18(5):69-74.

Ibrahim MM, Ottai MES, El-Mergawi RA (2007). Selfing mating effect on growth traits and silymarin production of some selected lines among milk thistle (Silybum marianum L.) varieties. World J Agric Sci 3(1):97-104.

Jančová P, Šiller M, Anzenbacherová E, Křen V, Anzenbacher P, Šimánek V (2011). Evidence for differences in regioselective and stereoselective glucuronidation of silybin diastereomers from milk thistle (Silybum marianum) by human UDPglucuronosyltransferases. Xenobiot 41:743-751.

Karkanis A, Bilalis D, Efthimiadou A (2011). Cultivation of milk thistle (Silybum marianum L. Gaertn.), a medicinal weed. Ind Crops Prod 34:825-830.

Katar D, Yaman H, Subasi I, Arslan Y (2013). Determination of some characteristics of M1 seedling of milk thistle (Silybum marianum (L.) Gaertn.) obtained by treatment of different doses of gamma irradiation. Süleyman Demirel Üniversitesi Ziraat Fakültesi Dergisi 8(1):78-83.

Kauntz H, Bousserouel S, Gossé F, Raul F (2012). The flavonolignan silibinin potentiates TRAIL-induced apoptosis in human colon adenocarcinoma and in derived TRAIL-resistant metastatic cells. Apoptosis 17(8):797-809.

Kavallieratos NG, Tomanović Z, Sarlis GP, Vayias BJ, Žikić V, Emmanouel NE (2007). Aphids (Hemiptera: Aphidoidea) on cultivated and self-sown plants in Greece. Biol 62:335344.

Kaźmierczak K, Seidler-Łożykowska K (1997). Silma, the Pol- ish variety of milk thistle (Silybum marianum L. Gaertn.). Herb Pol 43:195-197.

Khalili M, Hasanloo T, Kazemi Tabar S, Rahnama H (2009). Influence of exogenous salicylic acid on flavonolignans and lipoxygenase activity in the hairy root cultures of Silybum marianum. Cell Biol Int 33:988-994.

Khan MZ, Blackshaw RE, Marwat KB (2009). Biology of milk thistle (Silybum marianum) and the management options for growers in north-western Pakistan. Weed Biol Manag 9:99-105.

Khan SA, Hamid S, Sabir AW (1988). Development of spineless Silybum marianum. Pakistan J Sci Ind Res 31(8):585-586.

Kozera W, Nowak N (2004). The effect of fertilization on milk thistle (Silybum marianum) yield and its chosen features. Ann Univ Mariae Curie-Sklodowska Sect Agric 59(1):369374.

Kroll DJ, Shaw HS, Oberlies NH (2007). Milk thistle nomenclature: why it matters in cancer research and pharmacokinetic studies. Integr Cancer Ther 6(2):110-119.

Ledda L, Deligios PA, Farci R, Sulas L (2013). Biomass supply for energetic purposes from some Cardueae species grown in Mediterranean farming systems. Ind Crops Prod 47:218226.

Madrid E, Corchete P (2010). Silymarin secretion and its elicitation by methyl jasmonate in cell cultures of Silybum marianum is mediated by phospholipase D-phosphatidic acid. Jo Exp Bot 61:747-754.

Malekzadeh M, Mirmazloum SI, Mortazavi SN, Panahi M, Angorani HR (2011). Physicochemical properties and oil constituents of milk thistle (Silybum marianum Gaertn. cv. Budakalászi) under drought stress. J Med Plants Res 5(13):2886-2889.

Martin RJ, Lauren DR, Smith WA, Jensen DJ, Deo B, Douglas JA (2006). Factors influencing silymarin content and composition in variegated thistle (Silybum marianum). N Z J Crop Hortic Sci 34 (3):239-245.

Mohammadi SA, Shokrpour M, Moghaddam M, Javanshir A (2011). AFLP-based molecular characterization and population structure analysis of Silybum marianum L. Plant Genet Resour Charact Util 9:445-453.

Montemurro P, Fracchiolla M, Lonigro A (2007). Effects of some environmental factors on seed germination and spreading potential of Silybum marianum Gaertner. Ital J Agron 3:315-320.

Morazzoni P, Bombardelli E (1995). Silybum marianum (Carduus marianus). Fitoter 66(1):3-42.

Moscow D, Lindow SE (1989). Infection of milk thistle (Silybum marianum) leaves by Septoria silybi. Phytopathol 79:1085-1090.

Nyiredy S, Samu Z, Szücs Z, Gulácsi K, Kurtán T, Antus S (2008). New insight into the biosynthesis of flavanolignans in the white-flowered variant of Silybum marianum. J Chromatogr Sci 46:93-96. 
Ottai MES, Abdel-Moniem ASH (2006). Genetic parameter variations among milk thistle, Silybum marianum varieties and varietal sensitivity to infestation with seed-head weevil, Larinus latus Herbst. Int J Agric Biol 8:862-866.

Polyak SJ, Morishima C, Lohmann V, Pal S, Lee DYW, Liu Y, Graf TN, Oberliesf NH (2010). Identification of hepatoprotective flavonolignans from silymarin. Proceeding of the National Academy of Sciences of the United States of America 107(13):5995-5999.

Post-White J, Ladas EJ, Kelly KM (2007). Advances in the use of milk thistle (Silybum marianum). Integr Cancer Ther 6 (2):104-109.

Ram G, Bhan MK, Gupta KK, Thaker B, Jamwal U, Pal S (2005). Variability pattern and correlation studies in Silybum marianum Gaertn. Fitoter 76(2):143-147.

Rezwani A (2008). A new species, and a new record of a subspecies belonging to the genus Dysaphis (Homoptera: Aphididae) from Iran. J Entomol Soc Iran, 27:23-26.

Růžičková G, Fojtová J, Součková M (2011). The yield and quality of milk thistle (Silybum marianum (L.) Gaertn.) seed oil from the perspective of environment and genotype - a pilot study. Acta Fytotech Zootech 14(1):9-12.

Sagar SM (2007). Future directions for research on Silybum marianum for cancer patients. Integr Cancer Ther 6(2):166173.

Samu Z, Nyiredy S, Baitz-Gács E, Varga Z, Kurtán T, Dinya Z, Antus S (2004). Structure elucidation and antioxidant activity of (-)-isosilandrin isolated from Silybum marianum L. Chem Biodivers 1(11):1668-2677.

Sánchez-Sampedro MA, Fernández-Tarrago J, Corchete P (2005a). Yeast extract and methyl jasmonate-induced silymarin production in cell cultures of Silybum marianum (L.) Gaertn. J Biotechnol 119:60-69.

Sánchez-Sampedro MA, Fernańdez-Tarrago J, Corchete $\mathrm{P}$ (2005b). Enhanced silymarin accumulation is related to calcium deprivation in cell suspension cultures of Silybum marianum (L.) Gaertn. J Plant Physiol 162:1177-1182.

Sayar NP, Smith CA, White IM, Knio KM (2009). Terellia fuscicornis (Diptera: Tephritidae): biological and morphological adaptation on artichoke and milk thistle. J Nat Hist 43:1159-1181

Shokrpour M, Mohammadi SA, Moghaddam M, Ziai SA, Javanshir A (2008a). Analysis of morphological association, phytochemical and AFLP markers in milk thistle (Silybum marianum L.). Iran J Med Aromat Plants 41:278-292.
Shokrpour M, Mohammadi SA, Moghaddam M, Ziai SA, Javanshir A (2008b). Variation in flavonolignan concentration of milk thistle (Silybum marianum) fruits grown in Iran. J Herb Spices Med Plants 13(4):55-69.

Shokrpour M, Torabi Gigloo M, Asghari A, Bahrampour S (2011). Study of some agronomic attributes in milk thistle (Silybum marianum Gaertn.) ecotypes from Iran. J Med Plants Res 5(11):2169-2174.

Sidhu MC, Saini P (2011). Anatomical investigations in Silybum marianum (L.) Gaertn. J Res Biol 8:603-608.

Souissi T, Berner DK, Smallwood EL (2005). First report of smut caused by Microbotryum silybum on inovy thistle. Plant Dis 89:1242.

Sulas L, Ventura A, Murgia L (2008). Phytomass production from Silybum marianum for bioenergy. Options Méditer Ser A 79:487-490.

Szilági I, Téténzi P, Antus S, Selingmann O, Charim VM, Seitz M, Wagnerm H (1981). Structure of silandrin and silymonin. 2. New flavonolignans from a white blooming Silybum marianum variety. Planta Med 43:121-127.

Toyang NJ, Verpoorte R (2013). A review of the medicinal potentials of plants of the genus Vernonia (Asteraceae). J Ethnopharmacol 146 (3):681-723.

Tůmová L, Tůma J, Megušar K, Doležal M (2010). Substituted pyrazinecarboxamides as abiotic elicitors of flavolignan production in Silybum marianum (L.) Gaertn cultures in vitro. Mol 15:331-340.

Vaknin Y, Hadas R, Schafferman D, Murkhovsky L, Bashan N (2008). The potential of milk thistle (Silybum marianum L.), an Israeli native, as a source of edible sprouts rich in antioxidants. Int J Food Sci Nutr 9 (4):339-346.

Veres T, Tyr S (2012). Milk thistle (Silybum marianum (L.) Gaertn.) as a weed in sustainable crop rotation. Res J Agric Sci 44:118-122.

Zarrelli A, Romanucci V, Greca MD, De Napoli L, Previtera L, Di Fabio G (2013). New silybin scaffold for chemical diversification: Synthesis of novel 23-phosphodiester silybin conjugates. Synlett $24(1): 45-48$. 